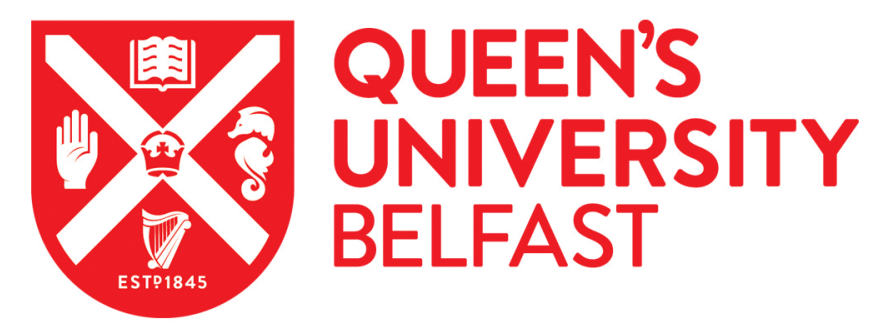

\title{
Introduction: Embodiment, Identity, and the Patient's Story
}

Wilson, S. (2016). Introduction: Embodiment, Identity, and the Patient's Story. L'Esprit Créateur, 56(2), 1-11. http://muse.jhu.edu/article/621996

\author{
Published in: \\ L'Esprit Créateur
}

Document Version:

Peer reviewed version

Queen's University Belfast - Research Portal:

Link to publication record in Queen's University Belfast Research Portal

Publisher rights

Copyright @ 2016 L'Esprit Créateur. This article first appeared in L'Esprit Créateur, Volume 56, Number 2, Summer 2016, , pages 1-11.

\section{General rights}

Copyright for the publications made accessible via the Queen's University Belfast Research Portal is retained by the author(s) and / or other copyright owners and it is a condition of accessing these publications that users recognise and abide by the legal requirements associated with these rights.

Take down policy

The Research Portal is Queen's institutional repository that provides access to Queen's research output. Every effort has been made to ensure that content in the Research Portal does not infringe any person's rights, or applicable UK laws. If you discover content in the Research Portal that you believe breaches copyright or violates any law, please contact openaccess@qub.ac.uk. 


\title{
Introduction: Embodiment, Identity, and the Patient’s Story
}

\author{
Steven Wilson
}

\section{ON THE OPENING PAGE of The Elements of Clinical Diagnosis (1898), one of the}

first texts to outline the fundamental processes of clinical diagnosis, George Klemperer, Professor of Medicine at the University of Berlin, notes that "The tasks of practical medicine are prophylactic and curative. A systematic treatment of disease rests upon the recognition of its forms and manifestations.” The science involved in the recognition of disease - which is Klemperer's definition of “diagnosis" - depends first and foremost on "The naming of the disease”. In order to get to that stage, a "diagnosis is reached by the examination of the patient. This consists in the obtaining of the history (anamnesis) and in the objective examination (status prajsens)" ${ }^{1}$ Klemperer's account illustrates two important points: first, that the standard medical case history has been the cornerstone of clinical practice for well over a century; and second, that medical practice - certainly since the development of science in the eighteenth and nineteenth centuries - has acknowledged its debt to the arts, and to the art of narrative in particular. When a doctor compiles a "medical history," he or she does so in the first instance by listening to the patient's "story" - his or her symptoms, feelings, and experiences. Taking due regard of other factors, including past medical history and family history, the doctor will proceed to a physical examination of the patient, a clinical assessment, and a treatment plan. In the transition from patient's "story" to treatment plan, science - especially medical knowledge - will take on an increasingly important role, relegating the subjectivity of the patient's experience to the background. Any incoherence in the suffering subject's account will be removed in a report whose narrative structure will aim for order and organization; confusion will be translated into a professional account; silences will be erased, and tears ignored; 
metaphors will find themselves replaced with specialised factual statements on symptoms and body chemistry; and the first-person pronoun will be replaced by the impersonal discourse of scientific objectivity. The relationship between patient and doctor will alter quite radically as a result: initially fulfilling the role of active, speaking subject, the patient will cede control of his or her narrative to the doctor when the focus shifts from diagnosis to treatment. Coming under the "medical gaze," as Foucault termed it in Naissance de la clinique (1963), the patient will be subjected to a dehumanizing separation of often minute entities of the body from his or her integral identity as a person experiencing a potentially bewildering, frightening, transformative experience. ${ }^{2}$

While there are significant affinities between medicine and narrative, the interplay between them is often characterized by a state of persistent tension rather than productive coexistence. As Arthur Frank puts it, the dominant authority of medicine conspires to "take away voice" - to overpower the patient's voice with a cacophony of specialist medical discourse, or what is euphemistically termed medical competence. ${ }^{3}$ In any analysis of what Oliver Sacks calls “clinical tales," questions of power, subjectivity, and knowledge come to the fore. ${ }^{4}$ Within the context of the relatively recent "narrativist turn in the human sciences," in which narrative is recognized as playing a central role in cross-disciplinary understandings of the sciences and social sciences, Martin Kreiswirth asks two questions pertinent to the articles presented in this volume: "Why have we decided to trust the tale? And what does this say about how we define, talk about, and organize knowledge?"5 The essays in this special issue of L'Esprit Créateur are based on the premise that the humanities in general, and narrative in particular, have a valuable contribution to make to attempts to understand what it is like to be ill, to suffer, to experience a life-changing condition, and/or to be facing death. Inspired by new approaches to illness, disorders, and disability offered by the medical humanities, scholars of literature, film, art, music, and digital media are shedding new light on complex, multifaceted experiences that 
medical discourse cannot adequately describe. This special issue of contributes to this endeavour: taking as their subject the role played by first-person narratives in making sense of the medical realities and the human experience of illnesses and disabilities, the contributions that follow combine to argue for a more richly-textured way of understanding the realities and representations of pain, suffering, and patienthood than medical accounts on their own could ever offer.

Reacting against the cultural commonplace that patients "surrender their bodies to medicine” (Frank 16), the emergence of so-called illness narratives corresponds to what David Shuttleton terms, in his book on smallpox, "a shift in approaches to medical history, away from creating a narrative of progressive 'breakthroughs' associated with an heroic cast of clinicians towards a more inclusive consideration of the embodied experience of the actual sufferers of a given disease.” ${ }^{6}$ Although illness narratives have been particularly prevalent over the last twenty-five years, they date back centuries; Montaigne's reflections on his frequent and severe experiences of renal colic in "De l'expérience," one of his sixteenth-century Essais, is often cited as a foundational exemplar of the genre. Notwithstanding a relatively undefined corpus of illness narratives emerging in the late nineteenth and early twentieth centuries (no doubt emblematic of the cultural shift away from religion as a control mechanism for dealing with fear, uncertainty, and suffering), it is in the second half of the twentieth century that we witness a flourishing of these texts. While such a trajectory may be explained by falling levels of trust in (particularly Western) medical systems, Thomas Couser has established parallels between the increase in writings expressive of illness and disability, and the rise of successive civil rights movements: these include women's liberation, whose support was instrumental to the development of breast cancer narratives; the gay rights movement, which actively promoted the writing of AIDS narratives; and the disability rights movement, which encouraged 
narratives giving voice to what it is to experience various kinds of disability. Illness narratives are therefore seen to reflect, and contribute to, the cultural landscape of their time. ${ }^{7}$

Academic and cultural studies have, in turn, responded to these trends. In 1993, Ann Hunsaker Hawkins published the first edition of her influential monograph, Reconstructing Illness: Studies in Pathography, a text cited by many of the contributors to this special issue. ${ }^{8}$ In what was the first major study to examine life writing on illness, Hunsaker Hawkins asserts that pathography - which she defines as "an autobiographical [...] narrative about an experience of illness” (Hunsaker Hawkins 229, note 1) - “restores the person ignored or canceled out in the medical enterprise, and it places that person at the very center. [...] In a sense," she goes on to state, "the pathography written by the patient or a loved one can be seen as the logical counterpart to the medical history written by the physician or by the medical staff assigned to a particular patient” (Hunsaker Hawkins 12). The deliberate choice of the term "autopathography" for the title of this special issue flows from a desire to distinguish between patient narratives and an emerging collection of so-called "filial memoirs"9 - and to emphasize that subjective patient experience is a legitimate source both of self-knowledge and of epistemological knowledge about the experience of illness and disability. Hunsaker Hawkins’s focus on patient subjectivity and empowerment provides the conceptual parameters for debates on the role that autopathography might play in challenging the power structures inherent in medicine: "it is in restoring the patient's voice to the medical enterprise that the study of [auto]pathography has its greatest importance and offers its greatest promise” (Hunsaker Hawkins xii). This is a point developed by Frank in The Wounded Storyteller (1995), in which he categorizes autopathographies into “restitution,” “chaos,” and “quest narratives.” What links the various types of illness narrative, he argues, is a desire for patients not to "surrender their bodies to medicine," but to "try to hold onto their own stories": "Telling stories of illness is the attempt, instigated by the body's disease, to give voice to an experience that medicine cannot 
describe” (Frank 16, 18). Two years after the publication of Frank’s text, Recovering Bodies: Illness, Disability and Life Writing appeared. ${ }^{10}$ In this study, Couser takes the idea of the autopathography as a voice against dominant discourses still further by examining the ways in which narratives on breast cancer, HIV/AIDS, paralysis, and deafness engaged with and, in some cases, challenged sexist, homophobic, and ableist points of view.

More recent studies have tended to emphasize the particular generic status of autopathography. In The Invading Body, Einat Avrahami explores terminal illness autobiographies in relation to theories of subjectivity and embodiment, and suggests that the limitations of the theoretical assumptions that underpin our understanding of autobiography are exposed when the writing subject of the personal narrative is ill:

Terminal illness narratives and photographs alert us to the problems that arise from treating historically specific bodies as textual, and rather passive, surfaces whose meaning is determined by social institutions and discourses. They question the prevailing poststructuralist perspective that has generated neat formulations of materiality, and of the body, as always already a discursive construct, the product of conscious or unconscious political inscription. ${ }^{11}$

Arguing that "neat theoretical formulations cannot accommodate the messy reality of the lived body," Avrahami proposes that autopathographies challenge "the view of the body as a secondary product of the normative discursive system" and highlight, instead, "the interrelatedness and interconstitutive dynamics of embodied experience and discursive constructs” (Avrahami 12). Avrahami's reflection on the value of subjectivity, how this contributes to existing knowledge about the body and selfhood, and how it sits alongside mainstream literary criticism sets the scene for Ann Jurecic's examination of the ways in which 
autopathographies have “reclaim[ed] patients' voices from the biomedical narratives imposed on them by modern science." ${ }^{12}$ As a result, she argues that autopathographies have "shifted the boundaries of literary study," so that they are now "central to the literary branch of medical humanism” (Jurecic 3). The premise for Jurecic’s study is that "the significance of the work performed by” personal narratives on the subjective experience of illness, while appreciated for its "pragmatic" worth in professional medical humanities schools, is undervalued when it comes to "the theoretical projects of scholars in the academy" (Jurecic 3).

By seeking to bridge the gap between narratives based on experiential testimony and “mainstream” academic discourses in their respective works, Evrahami and Jurecic provide an impetus for this collection of articles. Diverse approaches and methodologies will be used to consider first-person perspectives on a range of illnesses, disabilities, and disorders, including HIV/AIDS, cancer, physical pain, mental health issues, anorexia, and locked-in syndrome. Taken collectively, these articles aim to promote interdisciplinary dialogue across genres including literature, film, philosophy, and cultural studies - in a bid to further our understanding of the literary and aesthetic enterprise of writing the self. Deliberately resisting C. P. Snow's idea that the relationship between the "two cultures" of science and the arts is one of deep mutual suspicion, our approach examines the productive synergies and syntheses that emerge when medicine and the humanities - and first-person narratives, in particular - come together. ${ }^{13}$ Our overarching purpose is to probe the creative potential that lies at the interface of medicine and the arts, and to forge new understandings of the ways in which expressions of embodied experience can contribute to medicine’s empathetic endeavor to appreciate suffering and identify with the challenges of patienthood. In our bid to enquire, collaboratively, into what it is to be human and ill or disabled, and what first-person expressions of subjective experience can tell us about illness and disability, we situate ourselves within the expanding field of enquiry that is the medical humanities, as conceptualized by Martyn Evans and David Greaves: 
"if the humanities disciplines in general are linked by a concern to record, to interpret, and understand human experience, then the medical humanities are among other things those same disciplines recording, interpreting, and seeking to understand the human experience of health, illness, disability, and medical and health care.”14

If, methodologically, we seek to break down restrictive and artificial boundaries by looking at how narrative, representation, and cultural contexts enable a greater awareness of the role played by medical healthcare in the lives of its individual users, a second goal of this special issue is to bridge the chasm that currently exists between research on autopathography in the Anglophone and Francophone worlds. Critical investigations of autopathography have been centred resolutely on Anglophone accounts in recent years, mirroring the fact that all the most influential medical journals that debate "the language of medicine" have emerged from the Anglosphere. It is revealing that the major studies cited so far in this critical introduction to the theme of autopathography are published in English and have been written by scholars based primarily in the United States. Yet it is hardly surprising: as Alan Bleakley has shown, the medical humanities originated in North America and have subsequently grown in significance as a field of study in the United Kingdom and other Anglophone countries. ${ }^{15}$ While the term "les humanités médicales” has entered French lexicon only in recent years, studies have, of course, been conducted into first-person perspectives on illness in the Francosphere. Moreover, there is a rich and distinctive field of source material to engage with, as the title of Stéphane Grisi’s 1996 text, Dans l'intimité des maladies: De Montaigne à Hervé Guibert, attests. ${ }^{16}$ In his consideration of first-person expressions of illness in the "confessions," journals, and autobiographies of writers as diverse as Rousseau and Stendhal, Grisi focuses on writings that make reference to illness rather than take it as their major thematic concern. His definition of autopathography - “tout écrit autobiographique dans lequel l’auteur évoque, de façon centrale ou périphérique, des faits, des idées ou des sentiments relatifs à sa propre 
maladie” (Grisi 25) - is, therefore, more expansive than ours. Grisi's central preoccupation is to investigate the ways in which autopathography communicates with the reader and, in the process, reinscribes Lejeune’s theory of the "pacte autobiographique.” ${ }^{17}$ More recently, Arlette Bouloumié's collection of essays explores the "relations de la maladie et de l'écriture” by considering the textual structures used by first-person writers to accommodate the complex and often bewildering experience of illness, arguing that: "La littérature peut [...] aider la médicine soit en saisissant par le langage les symptômes et en aidant à déchiffrer leur message, le corps exprimant parfois ce que les mots ne parviennent pas à dire, soit en permettant de dire ce que la société refoule.”18 Finally, Valéria Milewski and Fanny Rinck, in their co-edited volume, assemble a collection of essays that examine the power of autopathography, which includes its potentially therapeutic function and its value in medical education to future "practiciens réflexifs." 19

This special issue differs from the studies cited above in that it investigates the relationship between body and self in first-person stories of illness or disability - specifically, the ways in which patienthood is bound up with a subjective understanding or knowledge of the body, and what Cole et al. term "moments of experiential significance and existential insight" that derive from the ways in which the ill or disabled self articulates bodily experience. ${ }^{20}$ If, as Rita Charon argues, the body “speaks” through autopathography, and the body anchors one's sense of self and one's relationship with others and the world, one of our aims is to reflect on the ways in which the body transmits knowledge. ${ }^{21}$ This transmission occurs through forms of expression that are literary and visual, and that use language and narrative ordering to transmit ideas, both to the patient and the outside world, allowing for new understandings of self and identity to emerge. ${ }^{22}$ The opening article, by Aude Fauvel, considers the writings (including family letters) of nineteenth-century artist Adèle Lauzier, which constitute some of the earliest French texts offering an account of repeated self-harm. In her 
analysis of Lauzier's first-person reflections, Fauvel notes that this daughter of a provincial military officer turns to self-harm for its emancipatory as well as aesthetic functions, in that it transforms the body into a work of art that Lauzier controls, allowing her to "affirmer sa liberté.” Anna Elsner, also concerned with questions of the aesthetic function of the body, begins her article with a reading of the tension between anonymity and intimacy that characterizes Jack Garofalo’s photograph of Malraux on his hospital bed in 1972. Elsner goes to on suggest that this tension finds expression in Malraux's Lazare, in which the author explores the destabilization of the self faced with illness and mortality. Unlike Lauzier's work, there is very little that is affirmative in Malraux's Lazare; on the contrary, Elsner argues that this text challenges the conventional wisdom that autopathography allows for the creation of a more holistic self, positing instead that illness is given meaning in the complete reduction of the self.

The next three articles engage with first-person writings on two of the twentieth century's most common diseases: cancer and HIV/AIDS. An analysis of Anne Cuneo's cancer autopathography, Une cuillerée de bleu, through the lens of phenomenology, opens up some powerful insights into the subjective realities of patienthood. As Sylvia Hübel and I argue, Cuneo's account reminds us that illness is perceived first and foremost by the patient as a disruption to what phenomenologists call the "lived body" - that is, her perception of her body, self, and social relationships. Charting the various instances of bodily alienation, fragmentation, and objectification in Cuneo's text gives an insight into what it is like to be a cancer patient. In this way, we propose that autopathographies can reveal valuable subjective knowledge of the lived experience of illness; and this knowledge, when situated alongside specialist medical knowledge, affords a more complete understanding of the realities of disease. The idea of bodily fragmentation also lies at the heart of Christelle Klein-Scholtz's article on Guibert's AIDS trilogy. Klein-Scholtz argues that the fragmented corpus textuel of 
Guibert's autopathographies emerges directly from the author's wounded body, and that the body is not only the subject but the source of his writing. A focus on the motif of contaminated blood - the very blood used to write Guibert's autopathographies - reinforces the suggestion that, in an act of textual transubstantiation, the presence of the body is discernible in a text that is the product of "transfusional" writing. Building on analyses of recent HIV/AIDS autopathographies, Enda McCaffrey extends his enquiry to include visual examples, such as André Techiné’s 2007 film, Les témoins. More fundamentally, he redirects the focus from accounts that take as their central concern representations of HIV/AIDS, and aims it at texts that rewrite knowledge of the disease. McCaffrey's article examines the shifting attitudes in the 1990s and beyond with respect to natural immune-therapies, arguing that their capacity to allow for natural governance of the body when faced with disease constitutes a response to, and rejection of, medical pathologization and the power of the pharmaceutical industry. The approaches to HIV/AIDS examined in the autopathograhical texts to which McCaffrey refers afford new understandings not only of managing illness, but of illness per se.

The following two articles provide fresh readings of one of the most cited texts in studies of autopathography - Le scaphandre et le papillon. Hannah Thompson, in her examination of Bauby's original account of life with locked-in syndrome, reads the text within the framework of critical disability studies. This approach, with its insistence on the centrality of embodiment, responds to and rejects the so-called medical model of disability which seeks to offer remedies that will allow the individual to overcome what is perceived to be a 'tragedy' in his or her life. While the medical model of disability is rejected by most Anglo-American scholars and activists, it is still surprisingly common in France. Thompson's analysis of Bauby's shift in subject position from 'non-disabled' to 'disabled' is premised on the key idea that Le scaphandre et le papillon challenges outdated notions of disability and, instead, celebrates the creative and intellectual potential of disability. In this way, she argues that Bauby 
reclaims agency from the power of medical authority and asserts his disabled subject position in the text, with the result that his autopathography challenges the dehumanizing, authoritative tendencies built into prevailing conceptions of disability. Following this, Claire Boyle, in her analysis of Julian Schnabel's 2007 understudied film adaptation of Bauby’s text, presents a compelling case for considering the cinema version in terms of Foucault's notion of a "technology of the self" in which the protagonist's altered self opens up the possibility of enhanced self-understanding and, in turn, permits him to assert his subjectivity. Boyle's analysis of the techniques of subjective cinema - including point-of-view shots that bring the spectator into the film world of Jean-Dominique, allowing us to adopt his perspective and giving the impression that we are somehow 'trapped' in his body - create what she terms a “cinema of embodiment” in which we are compelled to recognition. Drawing on contemporary readings of phenomenology in cinema, Boyle asserts that the implication of Schnabel's adaptation is that the viewer's response to Jean-Dominique's locked-in status is, itself, an embodied one.

The final two articles in this special issue focus on issues rarely voiced in literature until recently. Kathryn Robson, in her consideration of contemporary French anorexia narratives, invites us to turn our attention away from the visual gaze that traditionally frames the anorexic body within a culture of revulsion. Instead, Robson proposes that the first-person accounts of anorexia she focuses on are more profitably understood when approached from the theoretical standpoint of abjection (since the ingestion of food necessarily implies the transgression of boundaries between bodily interior and exterior) and, specifically, “abject relations” - a disconnect between the anorexic subject and food, others, and herself. Articulating the experience of anorexia in this way challenges popular conceptions of eating disorders including the supposition that they are generated by fear of the abject body - and also implicates the reader in a relationship with the anorexic self that is in itself "abject" and constitutive of an 
alternative paradigm for reading autopathography. In the concluding article, Áine Larkin sheds light on the problematic relationship between male-authored narratives of dependence and French constructions of masculinity in the works of Philippe Pozzo di Borgo and Philippe Vigand. Larkin traces these writers' shift in status from enjoying active lives in the public sphere to vulnerability and perceived weakness within the confines of the family home following accidents resulting in paralysis. In each case, identity renegotiations take place as Pozzo di Borgo and Vigand adapt to their impairment. Larkin considers their difficulty in resisting ableist ideology and reads their physical dependency in relation to heteronormative ideals of masculinity. As the vulnerable male comes under scrutiny, his sense of security and belief in himself is revealed to be dependent on a hegemonic notion of masculinity which disability challenges. Larkin's article thus closes the special issue with an apposite reminder that autopathography not only affords the reader privileged access to an understanding of what it is like to suffer from an illness, impairment or disability, but also has the potential to alter the writing subject's own self-awareness and self-worth.

The autopathographies examined in this special issue provide, through their attentiveness to shifting understandings of embodiment, an insight into the subjective experience of illness or disability. In addition to the contribution autopathography can make to self-knowledge or medical knowledge, the genre’s sensitivity to language, highlighted by many of the articles that follow, affirms that the author-narrator of autopathography gains a voice that is empowering. The challenge, then, is to listen to the "patient's voice" and to (re)value narrative as a vital element of good patient care. Rita Charon, in Narrative Medicine: Honoring the Stories of Illness, has proposed that narrative acts and medicine be combined in order to enhance the quality of medical practice: 
Without narrative acts, the patient cannot convey to anyone else what he or she is going through. More radically and perhaps equally true, without narrative acts, the patient cannot himself or herself grasp what the events of illness mean. And without telling about or writing about the care of a patient in a complex narrative form, the caregiver might not see the patient's illness in its full, textured, emotionally powerful, consequential narrative form. It remains to be proven - although it remains a most compelling hypothesis - that such narrative vision is required in order to offer compassionate care to the sick. (Cuneo 13)

An advocate for enhanced narrative competence on the part of medical professionals, Charon has argued that effective and humane healthcare depends on doctors' understanding of narrative, allowing them to "follow the patient's narrative thread, identify the metaphors or images used in the telling, tolerate ambiguity and uncertainty as the story unfold[s], identify the unspoken subtexts, and hear one story in the light of others” (Charon 4). Charon's seminal text, when read alongside the works by Frank, Causer, Hunsaker Hawkins, Avrahami, and Jurecic discussed earlier, illustrates the increasing attention being paid to the impact autopathography - in its many forms - is having in debates on the role of the arts and humanities in medical practice, in the United States at least. France and the Francophone world, with its rich tradition of first-person narratives of embodiment, illness, and disability, is wellplaced to influence such debates and benefit from them. While there is more work to be done, for example on the democratic and ethical issues raised by the prevalence of online autopathographies in recent years, it is nonetheless hoped that, in consort with the work of groups such as Voix des patients, which allows its users to share stories of medical experiences online, and concurrent academic studies into the contribution French and Francophone texts are making to world disability studies, this special issue of L'Esprit Créateur on French 
autopathography will play its part in furthering the oft-cited ideal of "patient-centred medicine.”23

Queen’s University Belfast

Notes

${ }^{1}$ George Klemperer, The Elements of Clinical Diagnosis, Nathan E. Brill and Samuel M. Brickner, trans. (London: Macmillan, 1898), 1.

${ }^{2}$ Michel Foucault, Naissance de la clinique (Paris: Presses Universitaires de France, 1994), 88.

${ }^{3}$ Arthur W. Frank, The Wounded Storyteller: Body, Illness and Ethics (Chicago: U of Chicago P, 1995), 7.

${ }^{4}$ Oliver Sacks, “Clinical Tales,” Literature and Medicine, 5 (1986): 16-23.

${ }^{5}$ Martin Kreiswirth, "Trusting the Tale: The Narrativist Turn in the Human Sciences," New Literary History, 23:3 (1992): 630.

${ }^{6}$ David E. Shuttleton, Smallpox and the Literary Imagination, 1660-1820 (Cambridge: Cambridge U P, 2007), 40.

${ }^{7}$ G. Thomas Couser, “Body Language: Illness, Disability, and Life Writing,” Life Writing, 13:1 (2016): 4.

${ }^{8}$ Anne Hunsaker Hawkins, Reconstructing Illness: Studies in Pathography, 2nd ed. (West Lafayette IN: Purdue U P, 1999).

${ }^{9}$ For more on the narrative of the illness experience in the context of the relationship between parent and child, see Thomas Couser, "Memoir and (Lack of) Memory: Filial Narratives of Paternal Dementia," in New Essays on Life Writing and the Body, C. S. Todd, ed. (Newcastle upon Tyne: Cambridge Scholars Publishing, 2009), 223-40. 
${ }^{10}$ G. Thomas Couser, Recovering Bodies: Illness, Disability and Life Writing (Madison: U of Wisconsin P, 1997).

${ }^{11}$ Einat Avrahami, The Invading Body: Reading Illness Autobiographies (Charlottesville: U of Virginia P, 2007), 12.

${ }^{12}$ Ann Jurecic, Illness as Narrative (Pittsburgh: U of Pittsburgh P, 2012), 2.

${ }^{13}$ C. P. Snow, The Two Cultures and The Scientific Revolution: The Rede Lecture 1959 (Cambridge: Cambridge U P, 1959).

${ }^{14}$ Martyn Evans and David Greaves, "Looking for Emerging Themes in Medical Humanities: Some Invitations to our Readers,” Medical Humanities, 29 (2003): 2

${ }^{15}$ For a discussion of the development of the "medical humanities," see Alan Bleakley, “Towards a 'Critical' Medical Humanities,” in Medicine, Health and the Arts: Approaches to the Medical Humanities, Victoria Bates, Alan Bleakley, and Sam Goodman, eds. (New York: Routledge, 2014), 17-26.

${ }^{16}$ Stéphane Grisi, Dans l'intimité des maladies: De Montaigne à Hervé Guibert (Paris: Desclée de Brouwer, 1996).

${ }^{17}$ Philippe Lejeune, Le pacte autobiographique (Paris: Seuil, 1975).

${ }^{18}$ Arlette Bouloumié, “Introduction,” in Écriture et maladie: “Du bon usage des maladies,” Arlette Bouloumié, ed. (Paris: Imago, 2003), 12.

${ }^{19}$ Valéria Milewski and Fanny Rinck, eds., Récits de soi face à la maladie grave (Limoges: Lambert-Lucas, 2014), 11.

20 Thomas R. Cole, Nathan S. Carlin, and Ronald A. Carson, Medical Humanities: An Introduction (New York: Cambridge U P, 2015), 136.

${ }^{21}$ Rita Charon, Narrative Medicine: Honoring the Stories of Illness (Oxford: Oxford U P, 2006), 86. 
${ }^{22}$ As Claire Charlotte McKechnie argues, narrativity should be considered in a broad sense in the context of the medical humanities, "because even (and sometimes especially) non-verbal expression requires language and narrative ordering in the construction of expression and in the process of meaning-making. Each time we make an effort to produce an expression of suffering, we demand a cognitive engagement that requires the ordering [of] information into narrative. We seek out communication; we desire the transmission of an idea. This is narrativity and it takes a myriad of forms.” Claire Charlotte McKechnie, “Anxieties of Communication: The Limits of Narrative in the Medical Humanities,” Medical Humanities, 40:2 (2014): 123.

${ }^{23}$ See the special issue "French and Francophone World Disability Studies," Journal of Literary and Cultural Disability Studies, Tammy Berberi and Christian Flaugh, guest eds. 10.2 (2016). 